\title{
A review on completing arsenic biogeochemical cycle: Microbial volatilization of arsines in environment
}

\author{
Peipei Wang ${ }^{1}$, Guoxin $\mathrm{Sun}^{1}$, Yan $\mathrm{Jia}^{1}$, Andrew A Meharg ${ }^{2}$, Yongguan Zhu ${ }^{1,3, *}$ \\ 1. State Key Laboratory of Urban and Regional Ecology, Research Center for Eco-Environmental Sciences, Chinese Academy of Sciences, Beijing \\ 100085, China \\ 2. Institute for Global Food Security, Queen's University Belfast, David Keir Building, Stranmillis Road, Belfast BT9 5AG, UK \\ 3. Key Lab of Urban Environment and Health, Institute of Urban Environment, Chinese Academy of Sciences, Xiamen 361021, China
}

\section{A R T I C L E I N F O}

\section{Article history:}

Received 06 March 2013

revised 23 May 2013

accepted 08 August 2013

\section{Keywords:}

arsenic

methylation

microorganism

volatilization

DOI: 10.1016/S1001-0742(13)60432-5

\begin{abstract}
A B S T R A C T
Arsenic (As) is ubiquitous in the environment in the carcinogenic inorganic forms, posing risks to human health in many parts of the world. Many microorganisms have evolved a series of mechanisms to cope with inorganic arsenic in their growth media such as transforming As compounds into volatile derivatives. Bio-volatilization of As has been suggested to play an important role in global As biogeochemical cycling, and can also be explored as a potential method for arsenic bioremediation. This review aims to provide an overview of the quality and quantity of As volatilization by fungi, bacteria, microalga and protozoans. Arsenic bio-volatilization is influenced by both biotic and abiotic factors that can be manipulated/elucidated for the purpose of As bioremediation. Since As biovolatilization is a resurgent topic for both biogeochemistry and environmental health, our review serves as a concept paper for future research directions.
\end{abstract}

\section{Introduction}

Inorganic arsenic, a class one, non-threshold human carcinogen (IARC, 1980, 1987), is ubiquitous in the natural environment. Arsenic contamination in the environment has been reported worldwide (Sohel et al., 2009; Li et al., 2011). There is increasing concern regarding As-related pollution due to various anthropogenic activities such as ore mining and smelting, use of As-containing fertilizers and pesticides, and fossil fuel burning. Natural sources, such as weathering and erosion of arsenic-containing rocks and soil are also important (Wang and Mulligan, 2006). Arsenic pollution in groundwater has been a serious health threat to the public human in SE, SW and NE USA, Inner Mongolia (China), SW Taiwan coastal regions, Sonora (Mexico), Pamplonian Plain (Argentina), West Bengal (In-

\footnotetext{
*Corresponding author. E-mail: ygzhu@ @rcees.ac.cn
}

dia), Northern Chile, and Bangladesh (Argos et al., 2010; Valette-Silver et al., 1999). The World Health Organization (WHO) deemed the As in Bangladeshi groundwater to be "the largest mass poisoning of a population in history" (Argos et al., 2010). Inorganic As enters the human through both drinking water and food, and in particular circumstances through respiratory exposure (Li et al., 2011). Inorganic As exposure can lead to a series of health problems including severe gastrointestinal disorders, hepatic and renal failure, cardiovascular disturbances, skin pigmentation, hyperkeratosis, and cancers in many organs such as the lung, bladder, liver, kidney, and skin (Agusa et al., 2010).

Nearly twenty As species can be commonly detected in the environmental and biological systems (Gong et al., 2002). These individual As species differ in their mobility, availability and toxicity. Arsenic exists primarily as inorganic arsenate $(\mathrm{As}(\mathrm{V}))$ and arsenite $(\mathrm{As}(\mathrm{III}))$ in the natural environment, and these are amongst the most 
toxic arsenic species. Inorganic As can be chemically or biologically methylated into mono-, di- or trimethylarsine. In vivo, the toxicity of soluble inorganic and organic As species are dimethylarsenite (DMAs(III)), monomethylarsenite $(\mathrm{MMAs}(\mathrm{III}))>\mathrm{As}(\mathrm{III})>\mathrm{As}(\mathrm{V})>$ dimethylarsenate, $(\operatorname{DMAs}(\mathrm{V}))$, monomethylarsenate $(\operatorname{MMAs}(\mathrm{V}))>$ trimethylarsine (TMAs), trimethylarsine oxide (TMAsO) (Akter et al., 2005). Inorganic arsine and mono-, di-, and trimethylarsine, denoted as $\mathrm{AsH}_{3}, \mathrm{MeAsH}_{2}\left(\left(\mathrm{CH}_{3}\right) \mathrm{AsH}_{2}\right)$, $\mathrm{Me}_{2} \mathrm{AsH}\left(\left(\mathrm{CH}_{3}\right)_{2} \mathrm{AsH}\right)$ and $\mathrm{Me}_{3} \mathrm{As}\left(\left(\mathrm{CH}_{3}\right)_{3} \mathrm{As}\right)$, termed collectively arsines, are a volatile class of trivalent arsenic compounds and can partition into the atmosphere from aqueous solution due to their low boiling points (Mestrot et al., 2013), as illustrated in Fig. 1. Though arsines are released into atmosphere, their concentration is still low due to the dilution of air. Arsine formation could effectively mitigate As poisoning in soils and water toward human or animals. On the other hand, As volatilization may lead to As transfer via the atmosphere (Bentley and Chasteen, 2002). Microorganisms have evolved dynamic mechanisms to cope with the toxicity of As in the environment. It has been estimated that as much as $2.1 \times 10^{7}$ $\mathrm{kg}$ As could be lost annually through volatilization from land surfaces to the atmosphere (Srivastava et al., 2011). Some microorganisms have been identified to form arsines for the decrease of intercellular As (Yin et al., 2011a, 2011b), including bacteria, fungi and algae (Table 1). Re- cently, it was reported that the presence of rice stimulated arsine production from paddy soils (mainly as TMAs), presumably through stimulation of microbial activities (Jia et al., 2012). The factors (organic matter amendments) regulating arsines formation from different soil types, sourced throughout the globe, have been reported (Mestrot et al., 2011).

This review summarizes the species of volatile As, and provides an overview of their formation by microorganisms such as fungi, bacteria, microalgae and protozoans. We discuss biotic and abiotic factors influencing As bio-volatilization, also provide examples of genetically engineered microbes for enhanced As volatilization, both of which can be manipulated/elucidated for the purpose of As bioremediation and understating the global As cycling.

\section{Volatile arsenic species}

Volatile arsenicals are defined as those As species with a boiling point (bp) below $150^{\circ} \mathrm{C}$. They can be formed either biotically, as intermediates or end products of the As biotransformation pathway by microorganisms, or abiotically (Fig. 1). With a boiling point of $-62.5^{\circ} \mathrm{C}$ (Planer-Friedrich et al., 2006), $\mathrm{AsH}_{3}$ is the most volatile As gas. $\mathrm{MeAsH}_{2}$ has a boiling point of $-2^{\circ} \mathrm{C}$ and $\mathrm{Me}_{2} \mathrm{AsH}+36^{\circ} \mathrm{C}$ (Planer-

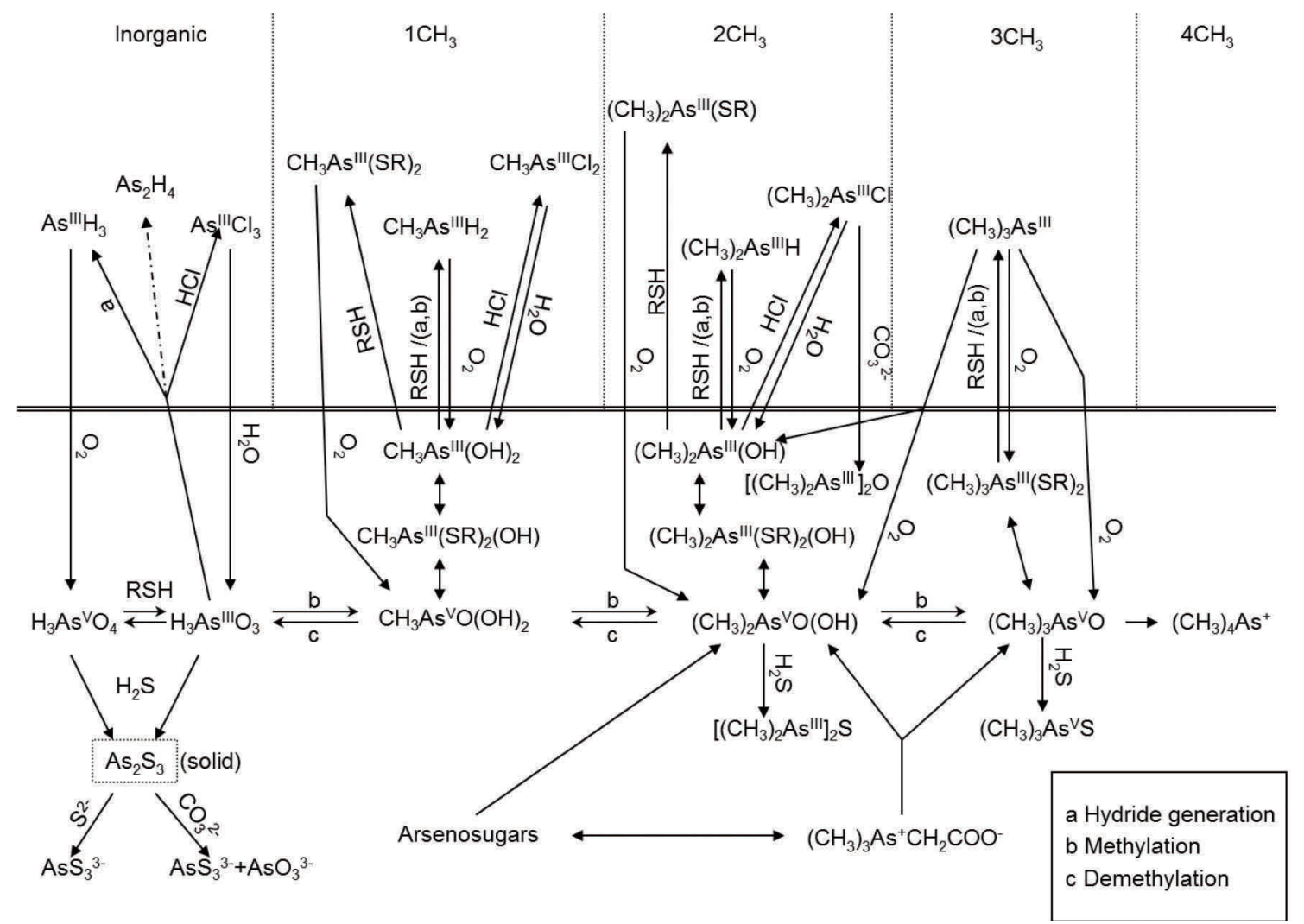

Fig. 1 Mutual transformation scheme of the more common inorganic and organic arsenic compounds in the hydrosphere and atmosphere. 
Table 1 Volatile arsenic species produced by various microorganisms

\begin{tabular}{|c|c|c|c|c|}
\hline Strain & Source & Volatile arsenic species & Substrate & Reference \\
\hline \multicolumn{5}{|l|}{ Fungi } \\
\hline Penicillium brevicaule & Plant & Trimethylarsine & $\begin{array}{l}\text { Arsenic acid, monomethylar- } \\
\text { sonic acid }\end{array}$ & Gosio, 1893 \\
\hline (Scopulariopsis brevicaulis) & & & Arsenic trioxide & Challenger, 1945 \\
\hline Мисог тисеdo & Bread & Trimethylarsine & - & Gosio, 1892 \\
\hline Cephalothecium & - & Trimethylarsine & - & Gosio, 1897 \\
\hline Sterigmatocystis & - & Trimethylarsine & - & Gosio, 1897 \\
\hline Paecilomyces & - & Trimethylarsine & $\begin{array}{l}\text { Methylarsonate, dimethylarsi- } \\
\text { nate }\end{array}$ & Gosio, 1897 \\
\hline Gliocladium roseum & Sewage & Trimethylarsine & $\begin{array}{l}\text { Methylarsonate, dimethylarsi- } \\
\text { nate }\end{array}$ & Cox et al., 1973 \\
\hline Penicillium sp. & Sewage & Trimethylarsine & & Cox et al., 1973 \\
\hline Candida humicola & Sewage & Trimethylarsine & $\begin{array}{l}\text { Arsenate, arsenite and methy- } \\
\text { larsonate, dimethylarsinate } \\
\text { Arsenate }\end{array}$ & Cox et al., 1973 \\
\hline Rhodotorula rubra & Seawater & Unkonwn alkylarsines & Arsenic trioxide & Vidal, 1980 \\
\hline Aspergillus glaucus & - & Trimethylarsine & Arsenic trioxide & Cullen and Reimer, 1989 \\
\hline Aspergillus uersicolor & - & Trimethylarsine & Monomethylarsonic acid & Cullen and Reimer, 1989 \\
\hline Penicillium chrysogenum & - & Trimethylarsine & Monomethylarsonic acid & Cullen and Reimer, 1989 \\
\hline Penicillium notatum & - & Trimethylarsine & Monomethylarsonic acid & Cullen and Reimer, 1989 \\
\hline Aspergillus fischeri & - & Trimethylarsine & & Cullen and Reimer, 1989 \\
\hline Ulocladium sp. & Cattle dip soils & Total volatile arsenic & Arsenate & Edvantoro et al., 2004 \\
\hline Aspergillus clavatus & Soil & Total volatile arsenic & Arsenic acid & Urik et al., 2007 \\
\hline Aspergillus niger & Soil & Total volatile arsenic & Arsenic acid & Urik et al., 2007 \\
\hline Trichoderma viride & Soil & Total volatile arsenic & Arsenic acid & Urik et al., 2007 \\
\hline Penicillium glabrum & Soil & Total volatile arsenic & Arsenic acid & Urik et al., 2007 \\
\hline Neosartorya fischer & Mining soil & Total volatile arsenic & Arsenate or arsenite & Cernansky et al., 2009 \\
\hline Fusarium oxysporum & Soil & Total volatile arsenic & - & Su et al., 2010 \\
\hline Neocosmospora sp. & Soil & Total volatile arsenic & Arsenate & Srivastava et al., 2011 \\
\hline Rhizopus sp. & Soil & Total volatile arsenic & Arsenate & Srivastava et al., 2011 \\
\hline \multicolumn{5}{|l|}{ Bacteria } \\
\hline Corynebacterium sp. & - & Dimethylarsine & Arsenate & Shariatpanahi et al., 1981 \\
\hline Escherichia coli & - & Dimethylarsine & Arsenate & Shariatpanahi et al., 1981 \\
\hline Proteus sp. & - & Dimethylarsine & Arsenate & Shariatpanahi et al., 1981 \\
\hline Pseudomonas sp. & - & $\begin{array}{l}\text { Mono-, di-, and trimethy- } \\
\text { larsine; arsine }\end{array}$ & Methylarsonate, arsenate & Shariatpanahi et al., 1981 \\
\hline Achromobacter sp. & - & Mono- and dimethylarsine & Methylarsonate & Shariatpanahi et al., 1983 \\
\hline Aeromonas sp. & - & Mono- and dimethylarsine & Methylarsonate & Shariatpanahi et al., 1983 \\
\hline Alcaligenes sp. & - & $\begin{array}{l}\text { Mono- } \\
\text { dimethylarsine; arsine }\end{array}$ & $\begin{array}{l}\text { Arsenate, arsenite, methylar- } \\
\text { sonate }\end{array}$ & Shariatpanahi et al., 1983 \\
\hline Flavobacterium sp. & - & Mono- and dimethylarsine & Methylarsonate & Shariatpanahi et al., 1983 \\
\hline Nocardia sp. & - & $\begin{array}{l}\text { Mono-, di-, and trimethy- } \\
\text { larsine }\end{array}$ & Methylarsonate & Shariatpanahi et al., 1983 \\
\hline Enterobacter sp. & - & Mono- and dimethylarsine & Methylarsonate & Shariatpanahi et al., 1983 \\
\hline Veillonella alcalescens & - & Trimethylarsine & Trimethylarsine oxide & Pickett et al., 1988 \\
\hline Streptoccus sanguis & - & Trimethylarsine & Trimethylarsine oxide & Pickett et al., 1988 \\
\hline Fusobacterium nucleatum & - & Trimethylarsine & Trimethylarsine oxide & Pickett et al., 1988 \\
\hline Bacillus subtilis & - & Trimethylarsine & Trimethylarsine oxide & Pickett et al., 1988 \\
\hline Staphylococcus aureus & - & Trimethylarsine & Trimethylarsine oxide & Pickett et al., 1988 \\
\hline Flavobacterium cytophaga & Soil & Trimethylarsine & Arsenite & Honschopp et al., 1996 \\
\hline Clostridium collagenovorans & Sewage sludge & Trimethylarsine & Arsenate & Michalke et al., 2000 \\
\hline Desulfovibrio gigas & Sewage sludge & Trimethylarsine & Arsenate & Michalke et al., 2000 \\
\hline Desulfovibrio vulgaris & Sewage sludge & Trimethylarsine & Arsenate & Michalke et al., 2000 \\
\hline Rhodopseudomonas palustris & Soil & Trimethylarsine & Arsenate or arsenite & Qin et al., 2006 \\
\hline
\end{tabular}




\begin{tabular}{|c|c|c|c|c|}
\hline Strain & Source & Volatile arsenic species & Substrate & Reference \\
\hline ASI-1 & Alluvial soil & $\begin{array}{l}\text { Mono-,di-, and } \\
\text { trimethylarsine; arsine }\end{array}$ & Arsenate & Meyer et al., 2007 \\
\hline \multicolumn{5}{|l|}{ Methanoarchaea } \\
\hline $\begin{array}{c}\text { Methanothermobacter } \\
\text { thermautotrophicus }\end{array}$ & Sewage sludge & Arsine & Arsenate & Michalke et al., 2000 \\
\hline Methanobacterium barkeri & Sewage digester & Arsine & Arsenate & Michalke et al., 2000 \\
\hline Methanosphaera stadtmanae & Human feces & $\begin{array}{l}\text { Di-, and } \\
\text { trimethylarsine }\end{array}$ & Arsenate & Michalke et al., 2007 \\
\hline Methanococcus vannielii & Marine mud & $\begin{array}{l}\text { Mono-,di-, and } \\
\text { trimethylarsine }\end{array}$ & Arsenate & Michalke et al., 2007 \\
\hline Methanoplanus limicola & Mud & Trimethylarsine & Arsenate & Michalke et al., 2007 \\
\hline Methanosarcina mazei & Sewage digester & Trimethylarsine & - & F. Thomas, unpublished \\
\hline Methanobacterium formicicum & Sewage digester & $\begin{array}{l}\text { Mono-, di-, and } \\
\text { trimethylarsine; arsine }\end{array}$ & Arsenate & Michalke et al., 2007 \\
\hline Methanobrevibacter smithii & Human feces & $\begin{array}{l}\text { Mono-, di-, and } \\
\text { trimethylarsine }\end{array}$ & Arsenate & Meyer et al., 2008 \\
\hline \multicolumn{5}{|l|}{ Eukaryotic microorganisms } \\
\hline Cyanidioschyzon sp. 5508 & Yellowstone Park & Trimethylarsine & Arsenite & Qin et al., 2009 \\
\hline Microcystis sp. PCC7806 & Aquatic systems & Trimethylarsine & Arsenite & Yin et al., 2011 \\
\hline Nostoc sp. PCC7120 & Aquatic systems & Trimethylarsine & Arsenite & Yin et al., 2011 \\
\hline Synechocystis sp. PCC6803 & Aquatic systems & Trimethylarsine & Arsenite & Yin et al., 2011 \\
\hline Tetrahymena pyriformis & Freshwater & Total volatile arsenic & Arsenate & Yin et al., 2011 \\
\hline
\end{tabular}

Friedrich et al., 2006). The completely methylated arsine, TMAs has a boiling point of $+52^{\circ} \mathrm{C}$ (Planer-Friedrich et al., 2006). All four of these arsines can be produced by microbes and all of them have been detected in natural samples (Planer-Friedrich et al., 2006; Meyer et al., 2007; Mestrot et al., 2011). Another inorganic volatile As compound, diarsine $\left(\mathrm{As}_{2} \mathrm{H}_{4}\right)\left(\mathrm{bp}: 100^{\circ} \mathrm{C}\right)$ and monomethylated volatile As compound, monomethyldiarsine $\left(\mathrm{CH}_{3}\right) \mathrm{As}_{2} \mathrm{H}_{3}$ (bp: unknown) were identified in the laboratory (Kösters et al., 2003), but to the best of our knowledge, both of them have not been detected in natural environmental samples so far.

$\mathrm{AsH}_{3}$ can cause immediate death at $150 \mu \mathrm{g} / \mathrm{m}^{3}$. When occurring at 25 to $50 \mu \mathrm{g} / \mathrm{m}^{3}$ for $30 \mathrm{~min}$ and $100 \mu \mathrm{g} / \mathrm{m}^{3}$ for less than $30 \mathrm{~min}$, it can lead to extensive hemolysis ending in death (Planer-Friedrich, 2004). $\mathrm{AsH}_{3}$ was even studied as a chemical warfare agent in World War II, though not yet used on the battlefield (Pakulska and Czerczak, 2006). In workplaces $\mathrm{AsH}_{3}$ may accidentally form as a byproduct during industrial processes. In nature, $\mathrm{AsH}_{3}$ formation can be resulted from the fungi-induced biotransformation of arsenic compounds (Pakulska and Czerczak, 2006). Acute toxicity potential for TMAs seems much lower than that for $\mathrm{AsH}_{3}$ (Cullen and Bentley, 2005). Arsines in natural systems readily react with oxygen and form non-volatile oxidation products, and this oxidation ultimately leads to the reduction of atmospheric total As. $\mathrm{AsH}_{3}$ is much more unstable, compared to other arsines, under normal atmospheric conditions, due to its rapid oxidation. After $120 \mathrm{hr}$ in the air, all $\mathrm{AsH}_{3}$ was oxidized to arsenic oxides
$\left(\mathrm{As}_{2} \mathrm{O}_{3}\right.$ or $\left.\mathrm{As}_{2} \mathrm{O}_{5}\right)$ (Pantsar-Kallio and Korpela, 2000). By contrast, TMAs is relatively stable in the air as it has been demonstrated that within 9 days only $30 \%$ of $10 \mu \mathrm{g}$ TMAs was oxidized to TMAsO (Pantsar-Kallio and Korpela, 2000). The difference in stability may explain why $\mathrm{AsH}_{3}$ is seldom detected in environmental samples, while TMAs is more dominant in the As gases released from environmental samples, e.g. Yellowstone National Park hot spring outgassing (Planer-Friedrich et al., 2006). Based on these reports, TMAs can persist and be transported long distance from its emission source, which is important for understanding the As biogeochemical cycle (Mestrot et al., 2013).

Volatile As-S and As-Cl compounds have been synthesized in the laboratory as early as in 1980s (Ashe and Ludwig, 1986; Tesfalidet and Irgum, 1988). It has been known that arsine can form volatile chloroarsine $\left(\mathrm{AsCl}_{3}\right)$ when in contact with $\mathrm{HCl}$ vapor. In addition to the inorganic $\mathrm{AsCl}_{3}$, the organic volatiles monomethylchloroarsine $\left(\mathrm{CH}_{3}\right) \mathrm{AsCl}_{2}\left(\mathrm{bp}: 133^{\circ} \mathrm{C}\right)$ and dimethylchloroarsine $\left(\mathrm{CH}_{3}\right)_{2} \mathrm{AsCl}$ (bp: unknown) have also been detected in the laboratory from natural sediment samples (Mester and Sturgeon, 2001). Because the sediment samples studied were sterilized before the experiment it seems that the formation of halides was abiotic. But when $\left(\mathrm{CH}_{3}\right)_{2} \mathrm{AsCl}$ was identified in the gas phase over a collected freshwater sediment core obtained from central Green Bay, Lake Michigan near a former As-containing herbicide factory (Killelea and Aldstadt, 2002), a hypothesis for $\left(\mathrm{CH}_{3}\right)_{2} \mathrm{AsCl}$ suggested its microbial action-related origin. $\left(\mathrm{CH}_{3}\right)_{2} \mathrm{AsCl}$ 
was also identified in the hydrothermal gases in Yellowstone National Park, as well as $\mathrm{As}\left(\mathrm{CH}_{3}\right)_{2} \mathrm{SCH}_{3}$ (Kösters et al., 2003). Outgassing from geothermal environment at Yellowstone National Park, the volatile As-S and As$\mathrm{Cl}$ species $\left(\left(\mathrm{CH}_{3}\right)_{2} \mathrm{AsCl},\left(\mathrm{CH}_{3}\right)_{2} \mathrm{AsSCH}_{3}\right.$, and $\left.\mathrm{CH}_{3} \mathrm{AsCl}_{2}\right)$ were in situ identified, along with TMAs (Planer-Friedrich et al., 2006). It has ever been suggested that some environmental factors, such as the reductive condition, sulphur-rich water, increased microbial activity, and high $\mathrm{H}_{2} \mathrm{~S}$ concentration in the hydrothermal gases, are conducive to the production of the sulphur-arseno compounds (Kösters et al., 2003). However, it is still unknown which microbe is responsible for the formation of volatile As-S or As- $\mathrm{Cl}$ compounds in the environment. Little information about the toxicities of the As-S and As- $\mathrm{Cl}$ gases are available. More investigations are needed for bio-formation and toxicities of volatile As-S and As-Cl compounds in the future.

\section{Microorganisms capable of volatilizing As}

\subsection{Fungi}

The role of fungi in arsenic volatilization was discovered possibly due to the wide use of arsenical pigments such as Scheele's green (copper arsenite), Schweinfurt green (Paris green), Vienna green, or Emerald green (copper acetoarsenite) in the 19th century (Challenger, 1945; Meharg, 2003). Severe cases of arsenical poisoning had occurred in Germany as early as 1815 (Challenger, 1945; Bartrip, 1994). It was suspected that in damp houses, the arsenical pigments in wallpapers could have given off toxic As compounds, which caused adverse effects on human health or even death. Bartolomeo Gosio, Italian physician, demonstrated that certain fungi converted a variety of inorganic As compounds to volatile forms and that these volatile arsenicals had garlic smell. Having known the fact that damp and moldy conditions favored the production of a garlic odor, Gosio originally isolated a garlic-odored gas producer, Mucor mucedo [sic], presumably the common bread mold, from a growing potato mash containing arsenic trioxide (arsenous oxide) (Gosio, 1892a). Afterwards, Gosio (1892b, 1893) isolated another fungus Penicillium brevicaule that was also particularly active in producing a garlic-odored gas. Continuously, more fungal species, Aspergillus glaucus, A. virens, Mucor ramosus, Cephalothecium roseum, and Sterigmatocystis ochracea, were identified to be able to volatilize As (Bentley and Chasteen, 2002). Because of the pioneering work on As volatilization, Gosio was acknowledged by naming volatile As compound as "Gosio gas". Gosio originally presumed that the garlic-odored gas was $\mathrm{Me}_{2} \mathrm{AsH}$ (Bentley and Chasteen, 2002). Until early 1930s, Challenger and his colleagues demonstrated that "Gosio gas" was TMAs, not $\mathrm{Me}_{2} \mathrm{AsH}$ (Challenger et al., 1933). Two strains of fungi isolated from sewage, belonging to Gliocladium roseum and a Penicillium sp., were shown to produce TMAs from substrates methylarsonate and dimethylarsinate under proper conditions. The third one, Candida humicola, produced small amounts of TMAs from As(V), As(III) and methylarsonate, with dimethylarsinate being the best substrate for volatilization when grown at pH 5.0 (Cox and Alexander, 1973b).

So far, fungal strains capable of transforming inorganic and organic As to volatile forms have been isolated from various environments. An inhabitant of cot mattress covers, Scopulariopsis brevicaulis and a wood decay fungus, Phaeolus schweinitzii, were examined to be good As volatilizers (Pearce et al., 1998). But fungal strains showed different capacities of As volatilization. The fungal species Penicillium sp. were capable of volatilizing 25.8-43.9 $\mu \mathrm{g}$ As from culture system containing $500 \mu \mathrm{g}$ As during a 5-day cultivation period (Visoottiviseth and Panviroj, 2001). When the initial As content in the culture system was $2500 \mu \mathrm{g}(50 \mathrm{mg} / \mathrm{L})$, A. clavatus biovolatilized 1522 $\mu \mathrm{g}$ As during a 30-day cultivation period (Čerňanský et al., 2007). However, it is difficult to compare the capacities of As volatilization by individual strain because of their different culture conditions, substrates, initial As concentrations among the different experimental settings. 3 pure fungal strains (A. niger, A. clavatus and Neosartorya fischeri) were demonstrated to volatilize As, with contrasting capacities under laboratory conditions. Approximately $16.9 \%-30.4 \%$ of As ( 0.143 to $0.257 \mathrm{mg}$ ) was volatilized from all culture media originally containing $0.848 \mathrm{mg}$ As(III), which represents $16.96 \mathrm{mg} / \mathrm{L}$ of As(III). On the other hand, the average amount of volatilized As from culture media originally containing $0.853 \mathrm{mg} \mathrm{As}(\mathrm{V})$, which represents $17.06 \mathrm{mg} / \mathrm{L}$ of $\mathrm{As}(\mathrm{V})$, was $10.9 \%-22.5 \%$ ( 0.093 to $0.191 \mathrm{mg})$, respectively. It revealed that the order of As bio-volatilization rate was $N$. fischeri $>A$. clavatus $>$ A. niger (Čerňanský et al., 2009). Similarly, 3 other fungi strains (P. janthinellum, Fusarium oxysporum and Trichoderma asperellum) were also investigated and were shown to have contrasting As volatilization capacities under laboratory conditions (Su et al., 2010). F. oxysporum showed the highest As volatilization rate, with $304 \mu \mathrm{g}$ after 15 days, in the culture system amended with $2500 \mu \mathrm{g}$ As(V). Moreover, arsines volatilized by 5 filamentous fungi (A. clavatus, A. niger $A / B, T$. viride and $P$. glabrum) were examined. After 30 -day cultivation, these fungi volatilized $0.010-0.067 \mathrm{mg}$ (4.0\% to $26.8 \%$ ) and $0.093-0.262 \mathrm{mg}$ (9.3\% to $26.2 \%$ ) of As from cultivation systems enriched with 0.25 and $1.00 \mathrm{mg}$ of As, respectively. Of the five strains, the most efficient arsenic-volatilizing organisms were $P$. glabrum and A. niger A strains (Urík et al., 2007). One recent investigation showed that 15 fungal strains isolated from As contaminated $(9.5-15.6 \mathrm{mg} / \mathrm{kg}$ ) 
agricultural soils from the state of West Bengal, India, were evaluated for their biological potential to remove As. The mean percent of As removal from liquid medium by volatilization ranged from $4 \%$ to $30 \%$. The most effective removals of As were observed in the Trichoderma sp., sterile mycelial strain Neocosmospora sp. and Rhizopus sp. fungal strains (Srivastava et al., 2011). These results not only proposed the application of fungi cultivation for As removal and bioremediation, also supposed that the amount of released arsines from soils, sediments and waters by indigenous fungi may be enhanced by the optimization of environmental parameters affecting volatilization, such as the addition of soil nutrients and moisture and aeration regulation (Thompson-Eagle et al., 1989; Frankenberger and Arshad, 2001).

\subsection{Bacteria}

It was discovered that when ${ }^{14} \mathrm{C}$-labeled cacodylic acid (CA; hydroxydimethylarsine oxide) was added to soil samples, about $60 \%$ of CA was converted to a volatile organoarsenical under anaerobic flooded conditions (Woolson and Kearney, 1973). This gave rise to the speculation that As volatilization may have resulted from a mixed bacterial culture because fungal growth would have been unlikely in this anaerobic environment (Woolson and Kearney, 1973).

A recent report has shown that As methylation in soils increases with the decreasing in redox potential (Eh), suggesting that As volatilization may be more efficient under anaerobic conditions (Frohne et al., 2011). The majority of work on As volatilization has focused on bacteria in the anaerobic ecosystems. Meyer et al. (2007) isolated a strictly anaerobic Gram-positive strain from an alluvial soil, which showed a versatility in transforming metal(loid) ions including As to volatile derivatives. This strain was affiliated to the species Clostridium glycolicum and was suggested to represent a dominant member of the metal(loid) volatilizating population in this habitat (Meyer et al., 2007). Intestinal microbiota, dominated by anaerobic bacteria and archaea, are important in facilitating As volatilization (Eckburg et al., 2005). In a study involving that human feces were sampled to study the role of intestinal microbiota in volatilizing metal(loids) including As, the production rates of arsines ranged from 0.7 to 5 $\mathrm{pmol} /(\mathrm{hr} \cdot \mathrm{kg}$ ) (dry weight), while the total As content of the samples was about $1.3 \mu \mathrm{mol} / \mathrm{kg}$ (dry weight) (Michalke et al., 2008). More recently, an in vitro gastrointestinal model, the simulator of the human intestinal microbial ecosystem (SHIME) has been developed to investigate volatilization of metal(loid)s by human intestinal microbiota (Van de Wiele et al., 2010). It was shown that intestinal bacteria had capacities to volatilize As and other metal(loid)s, increasing the mobility of metal(loid)s. Furthermore, significant amounts of mixed As/S metabolites were detected in the gas phase of the intestinal incubation process, of which two metabolites, $\left(\mathrm{CH}_{3}\right)_{2} \mathrm{AsSSCH}_{3}$ and $\mathrm{CH}_{3} \mathrm{As}\left(\mathrm{SCH}_{3}\right)_{2}$, were described for the first time in environmental matrices (Diaz-Bone and Van de Wiele, 2009).

Aerobic bacteria also exhibited the ability of As volatilization. One aerobic bacterium, belonged to the Flavobacterium-Cytophaga group, was isolated from As contaminated soil. The highest TMAs in the gas phase of the flasks was obtained after incubating the bacterium for $48 \mathrm{hr}$ in a medium containing $5 \mathrm{mg} \mathrm{As}(\mathrm{III})$, and $10 \%$ of As(III) was transformed to TMAs (Honschopp et al., 1996). Indeed, a study from India showed that kinds of Asvolatilizing indigenous bacteria (aerobic, anaerobic and facultative) were isolated from contaminated alluvial soil and their ability to form arsines was assessed. Approximately $37 \%$ of As(III) (under aerobic conditions) and $30 \% \mathrm{As}(\mathrm{V})$ (under anaerobic conditions) were volatilized by new bacterial isolates in 3 days (Majumder et al., 2013). Cyanobacteria (blue-green algae) are autotrophic prokaryotes performing oxygenic photosynthesis similar to that of higher plants. They are widespread in aquatic environments or soils and are one of the main representatives in the microbiota of such sites attributed to rapid growth. Cyanobacteria have been demonstrated to volatilize As (Yin et al., 2011a). Given the high abundance of cyanobacteria in fresh water environment and soils, these microbes may play a significant role in the biogeochemical cycling of As in aquatic systems.

Arsine species volatilized by different bacterial strains differ from one to another (Table 1). Three bacterial species, Corynebacterium sp., E. coli, and Proteus sp., produced $\mathrm{Me}_{2} \mathrm{AsH}$ (Shariatpanahi et al., 1981). Six bacterial species (Achromobacter sp., Aeromonas sp., Alcaligenes sp., Flavobacterium sp.,) produced both $\mathrm{MeAsH}_{2}$ and $\mathrm{Me}_{2} \mathrm{AsH}$ from methylarsonate; Pseudomonas sp. and $\mathrm{No}$ cardia sp. produced TMAs besides $\mathrm{MeAsH}_{2}$ and $\mathrm{Me}_{2} \mathrm{AsH}$ at the same time (Shariatpahani et al., 1983). In other words, Pseudomonas sp. and Nocardia sp. can produce all of the volatile methylarsines from this substrate. Pseudomonas and Alcaligenes also produced $\mathrm{AsH}_{3}$ from both $\mathrm{As}(\mathrm{III})$ and $\mathrm{As}(\mathrm{V})$ under anaerobic conditions (Cheng and Focht, 1979). According to Wickenheiser's research, TMAs is the only volatile As species formed by sulfatereducing bacteria and the peptolytic bacteria Clostridium collagenovorans, Desulfovibrio gigas and D. vulgaris (Wickenheiser et al., 1998; Michalke et al., 2000). Though TMAs is prone to be oxidized to nonvolatile TMAsO in water environment, TMAsO can be reduced de novo under aerobic or anaerobic conditions by several bacteria. Staphylococus aureus was the most active anaerobic bacterium, reducing TMAsO to TMAs from samples of river, sea sediment, sewage sludge (208 nmol/(min.g)) (cells). The most active aerobic bacterium with this feature belonged to a marine Pseudomonad (585 nmol/(min. g)) (cells) (Pickett et al., 1988). Consequently, TMAs can always be the predominant species above anaerobically incubated sewage sludge. 


\subsection{Methanoarchaea}

In anaerobic human gut, marine mud, drilling swamp mud and sewage sludge, where methane is produced as well as volatile metals and metalloids, there is large number of anaerobic methanoarchaea capable of volatilizing As (Bachofen et al., 1995; Michalke et al., 2000). Biomethylation and bio-volatilization of metals and metalloids, As in particular, is very similar to methane biosynthesis and is possibly an inherent feature of methanoarchaea (McBride and Wolfe, 1971; Meyer et al., 2008; Mestrot et al., 2013). Almost all methanoarchaea studied were capable of volatilizing a broad spectrum of metal(loid)s (As, Se, $\mathrm{Sb}, \mathrm{Te}$, and $\mathrm{Bi}$ ). Moreover, the diversity of the volatile derivatives produced and their emission rates were significantly higher in methanoarchaea than in bacterial strains (Meyer et al., 2008). It has been reported that anaerobic methanoarchaea, as well as autotrophic sulfate-reducing bacteria, execute one process called methylcobalamin $\left(\mathrm{CH}_{3} \mathrm{Cob}(\mathrm{III})\right)$-dependent methylation of As (McBride and Wolfe, 1971; Choi et al., 1994; Michalke et al., 2002). The mechanism of volatilizing arsenic is probably linked with the methanogenesis pathway and certainly involves methylcobalamin as a methyl donor (Thomas et al., 2011). The ratio between $\mathrm{CH}_{3} \mathrm{Cob}(\mathrm{III})$ and $\mathrm{Cob}(\mathrm{I})$ (Cob(I)alamin), the central intermediate of methanogenesis, was decisive in whether methylation or inorganic hydride generation of metal(loid)s was preferred (Thomas et al., 2011). In general, the species of volatile As generated by different methanoarchaea varies (Meyer et al., 2008). All four volatile As compounds, $\mathrm{AsH}_{3}, \mathrm{MeAsH}_{2}$, $\mathrm{Me}_{2} \mathrm{AsH}$, TMAs, can be produced by pure culture of the archaea Methanobacterium formicicum over the range of 0.05 to $0.3 \mathrm{mmol} \mathrm{KH}_{2} \mathrm{AsO}_{4}$. Methanosphaera stadtmanae, Methanobrevibacter smithii and Methanococcus vannielii all produced organic volatile As, but no $\mathrm{AsH}_{3}$. TMAs was only volatile product for Methanoplanus limicola and Methanosarcina mazei (Meyer et al., 2008). By contrast, Methanobacterium barkeri produced only $\mathrm{AsH}_{3}$. Methanobacterium thermoautotrophicum produced $\mathrm{AsH}_{3}$ with small amounts of $\mathrm{Me}_{2} \mathrm{AsH}$ (Bachofen et al., 1995).

\subsection{Other eukaryotic microorganisms}

Most studies of microbial communities on volatilizing As have focused on fungi, bacteria and archaea, with little attention to other eukaryotic microorganisms, such as aquatic alga and protozoans. A few eukaryotic microorganisms have been proved to volatilize As. A Yellowstone thermoacidophilic eukaryotic alga, Cyanidioschyzon sp. isolate 5508 reduced $\mathrm{As}(\mathrm{V})$ to $\mathrm{As}(\mathrm{III})$, and methylated As(III) to TMAs and DMAs at an optical temperature of 60-70 ${ }^{\circ} \mathrm{C}$ (Qin et al., 2009). Furthermore, the 2 recombinant As methyltransferases, CmArsMs were purified from Cyanidioschyzon sp. isolate 5508 and shown to transform As(III) into TMAs and TMAsO, with optical temperature of $60-70^{\circ} \mathrm{C}$ (Qin et al., 2009). A marine green microalgae
Ostreococcus tauri was demonstrated to have ability of As bio-volatilization (Zhang et al., 2013). These studies not only illustrate the contribution of eukaryotic microorganisms to the biogeochemical cycling of As, but also reveal the characterization of algal methyltransferases, as one of the molecular explanations for how these algae tolerate As. In freshwater environments, a genus of eukaryotic protozoan, Tetrahymena pyriformis, is active in methylating As (Zhang et al., 2012). T. pyriformis was shown to volatilize 12.1-19.7 ng and 15.8-30.8 ng As within the concentration range of 2-20 $\mu \mathrm{mol} \mathrm{As}(\mathrm{V})$, after 48 and $72 \mathrm{hr}$ treatments, respectively. At a concentration of $40 \mu \mathrm{mol} \mathrm{As}(\mathrm{V})$, the released volatile As increased significantly, up to 68.5 and $83.5 \mathrm{ng}$, respectively, indicating that the appropriate initial As dose may facilitate the formation of gaseous arsenic compounds (Urík et al., 2007; Yin et al., 2011b).

\section{Factors influencing As bio-volatilization}

\subsection{Biostimulation and bioaugmentation}

Microbial volatilization is one of the potential bioremediation technologies for removing As from wastewater or contaminated soil. Biostimulation is the process in which a stimulus to the microorganisms that already exist in the site is added, such as nutrients and other growth substrates, together with electron donors and acceptors, aiming at enhancing microbial activities of removing As from the site. Studies showed that As volatilization had a direct relationship with nutrient levels and microbial growth (Akins and Lewis, 1976; Sanford and Klein, 1988; Edvantoro et al., 2004). In the experiments on removing As compounds, when organic matter was added, small amounts of innate As present in retorted shale could be volatilized (Sanford and Klein, 1988). About 0.041\%$0.403 \%$ of As was volatilized from soil (containing $1 \mathrm{mg}$ total As, as sodium cacodylate) amended with different amounts of cellulose during a 70-day incubation period (Gao and Burau, 1997). The greatest reduction of As over 5-month incubation was up to $8.3 \%$ of the initial As concentration when contaminated soils were supplemented with $30 \%(W / W)$ manure and maintained at $75 \%$ field capacity (Edvantoro et al., 2004). Arsenic volatilization by anaerobic methanogenic bacteria were enhanced by adding inexpensive nutrient such as cow dung under laboratory condition. Maximum As volatilization (35\%) was obtained at a substrate (cow dung) concentration of $25 \mathrm{~g} / \mathrm{L}$ and initial As concentration of $30 \mathrm{mg} / \mathrm{L}$ (Mohapatra et al., 2008). It is possible that the methylating microbes present in the supplied manure increased As loss from the soils (Cullen and Reimer, 1989). The factors affecting As volatilization were investigated in pre-dried and fresh As contaminated paddy soils. Arsenic volatilization from paddy soil was demonstrated and increased with organic matter (OM) 
amendment, such as clover and dried distillers grain (DDG) (Huang et al., 2012). Arsenic volatilization from the treatments amended with sterilized or non-sterilized DDG was hundreds of times higher than the control. About $0.006 \%-0.013 \%$ of total soil As (about $3.7 \pm 0.2 \mathrm{mg}$ ) or 228-490 ng of As was volatilized from treatments with $\mathrm{OM}$ addition in a 30-day incubation. Both sterilized and non-sterilized DDG addition showed similar As volatilization, indicating that the microbes attached to OM did not significantly influence As volatilization. Perhaps OM addition stimulated indigenous microbial activity (Turpeinen et al., 2002; Edvantoro et al., 2004). A recent study suggested that the increased As volatilization in soil after the addition of OM (rice straw) might be ascribed to the increased abundance of As methylating microbes (harboring the arsM gene) (Jia et al., 2013). Arsenic methylation and volatilization can be affected by other abiotic factors. One laboratory study systematically examined the effects of As form, As concentration, soil moisture, soil temperature on As volatilization rates in samples of a Sacramento silty clay soil. Arsine evolution rate from the added substrate followed the order: DMAs $(\mathrm{V})>\operatorname{MMAs}(\mathrm{V})>\operatorname{As}(\mathrm{III})=$ As(V) (Gao and Burau, 1997). Microbial formation of methylated As was enhanced when soil was maintained under moist conditions and the optimum soil moisture level was between 250 and $350 \mathrm{~g} \mathrm{H}_{2} \mathrm{O} / \mathrm{kg}$ soil (Sanford and Klein, 1988; Gao and Burau, 1997; Edvantoro et al., 2004). Urine was less effective than manure in enhancing the loss of As from two cattle dip soils during the 5-month incubation (Edvantoro et al., 2004). The soils amended with urine had $\mathrm{pH}$ values ranging from 7.5 to 8.6, which might not be a suitable $\mathrm{pH}$ range for As methylation by microbes. In previous work, the optimum $\mathrm{pH}$ found for the evolution of volatile arsines was between 5 and 6 (Cox and Alexander, 1973a; Huysmans and Frankenberger, 1991). In the medium containing $100 \mathrm{mg} / \mathrm{L}$ methylarsenic acid (MAAs), the addition of amino acids (tryptophan, leucine, valine, phenylalanine, isoleucine and glutamine) promoted TMAs production by Penicillium sp., isolated from evaporation of pond water, with an enhancement ranging from 10.2 to 11.6-fold over the control without amino acid supplementations (Huysmans and Frankenberger, 1991). However, the following amino acids suppressed TMAs production in the presence of MAAs: lysine, serine, proliae, methionine, cysteine, glutamic acid, arginine, threonine, asparagine, aspartic acid, histidine, and glycine. The effects of amino acids metabolism on As methylation process in fungi are still obscure and need to be studied further.

Augmentation by inoculation of fungi (Penicillium sp. and Ulocladium sp.) was shown to increase the rates of As volatilization by 3.7- and 8.3-fold in contaminated and Asspiked soils (equivalent to $1390 \mathrm{mg} \mathrm{As} / \mathrm{kg}$ ), respectively (Edvantoro et al., 2004). The reason for relatively small amount of arsines evolved from uninoculated As contaminated soils may be that these soils either lacked microbial communities methylating As or restricted native microbial activities (Cullen and Reimer, 1989).

\subsection{Genetic modification for enhancing As volatiliza- tion}

Although many microorganisms have been shown to volatilize As, exploring the potential of microbial volatilization for bioremediation is still under considerable debate because of their low efficiency. It is reported that, in three sandy loam soils highly contaminated with As (2125-3632 mg/kg) from Southern Finland, the transformation of $\mathrm{As}(\mathrm{V})$ to $\mathrm{As}(\mathrm{III})$ and methylated products under aerobic and anaerobic conditions was less than $0.5 \%$, of which the production of TMAs only represented $0.02 \%-$ $0.3 \%$ (Turpeinen et al., 2002). Some genetic strategies have been proposed to enhance microbial volatilization. Since the enzyme Cyt19 that methylates As(V) and As(III) was identified first in rats (Lin et al., 2002), a large number of bacterial or archaeal genes homologous of Cyt19 have been characterized. To date, 200 homologues have been identified in genome databases, 7 in archaea, 13 in fungi, 17 in metazoa, and 163 in bacteria (Bhattacharjee and Rosen, 2007). A subset of these genes has been termed $\operatorname{ars} M$ and their protein product ArsM (arsenite S-adenosyl methyltransferase). The ars $M$ gene from soil bacterium Rhodopseudomonas palustris was first cloned and expressed in an arsenic-hypersensitive strain of $E$. coli (Qin et al., 2006). Transformed cells methylated and volatilized As, as a pathway of removing As from the medium and cells. Sequences homologous with ars $M$ of $R$. palustris can been found in more than 120 prokaryotic or eukaryotic species. From the multiple-sequence alignment in fungi, bacteria, archaea, alga, cyanobacteria and mammalian, we can identify conserved motifs and regions of considerable variability among the As methyltransferases (Ye et al., 2012). Perhaps diverse ArsM structures endow their different activities of methylating and volatilizing As. The arsMs, with higher activities for volatilizing As, are suggested to be transformed into indigenous bacteria in contaminated water and soil, as an inexpensive, efficient tool, and may be applied in bioremediation of As. The arsM from R. palustris have been successfully expressed in Sphingomonas desiccabilis and Bacillus idriensis, resulting in a 10-fold increase in As volatilization compared to the wild type in aqueous system. In soil system, about $2.2 \%-4.5 \%$ of As was removed by bio-volatilization during 30-day incubation (Liu et al., 2011). However, ArsM expression from a plasmid in above experiment limits their utility. The ars $M$ gene from Chlamydomonas reinhardtii was integrated into the chromosome of Pseudomonas putida, which does not have ars $M$ and does not methylate As. Within $16 \mathrm{hr}$, P. putida expressing ars $M$ transformed nearly all of the inorganic arsenic in the culture medium to the less toxic methylated species, including MMAs(V), DMAs(V), TMAsO, and 
eventually DMAs(III) and TMAs gases (Chen et al., 2013). Since $P$. putida have a relatively high population density in the rhizosphere, the engineered cells can be used for the rhizo-remediation. These results make us optimistically believe that we can remove As from the contaminated sites by the microorganisms with As methyltransferases. It is generally believed that plants cannot produce and volatilize TMAs as microorganisms do (Zhao et al., 2009). However, transgenic rice plants expressing the ars $M$ gene from $R$. palustris induced As methylation and volatilization (Meng et al., 2011). This proved the concept of using genetic modification to develop efficient phytoremediation (phytovolatilization) methods for contaminated soils and water.

\section{Conclusions and perspectives}

Although As volatilization has been known for decades, and it is generally believed that microbes play important roles in driving volatilization in the environment. However, only recently the molecular mechanisms underlying microbial As methylation and volatilization are being unraveled. Nonetheless, these mechanistic studies are mostly carried out on pure cultures, with little information on the linkage between microbial communities (both functional diversity and abundances) and bio-volatilization. Future studies are needed to examine the relationship between As bio-volatilization and environmental factors, biotic or abiotic, at different temporal and spatial scales. These studies should generate information upon which practical measures can be developed and applied to manipulate As bio-vitalization, both for bioremediation and mitigating the health risks of As (inorganic vs. organic As species) accumulated in food crops.

Although fluxes of As volatilization have been measured in some field sites (Mestrot et al., 2011), As bio-volatilization from soils have been investigated mostly under laboratory conditions. Therefore, in the future, more systematic flux data are needed for the development of predictive models that can be used to estimate the contribution of As bio-volatilization to overall global As biogeochemical cycle. These flux data should also come from marine environment, since marine biota appears to be particularly efficient in transforming low level inorganic As into organic forms (Maher and Butler, 1988; Kohlmeyer et al., 2002), yet, little is known about the scale of As biovolatilization from the ocean.

The practical aspect of As bio-volatilization is its potential applications in bioremediation of As-contaminated environments. The efficiency of As bio-volatilization is low and efforts should be directed to optimize environmental conditions to maximize the process. In addition, efficiently genetic engineering technologies, fully exploring the power of modern molecular biology, such as synthetic biology should be employed to enhance micro- bial capacity of volatilizing As to atmosphere. Integrated solutions should be developed for the field application of As bio-volatilization technologies.

\section{Acknowledgments}

This work was supported by the National Natural Science Foundation of China (No. 21077100, 41090284).

\section{R E F E R E N C E S}

Agusa, T., Kunito, T., Kubota, R., Inoue, S., Fujihara, J., Minh, T. B. et al., 2010. Exposure, metabolism, and health effects of arsenic in residents from arsenic-contaminated groundwater areas of Vietnam and Cambodia: A review. Rev. Environ. Health 25, 193-220.

Akins, M. B., Lewis, R. J., 1976. Chemical distribution and gaseous evolution of arsenic- ${ }^{74}$ added to soils as DSMA- ${ }^{74}$ As. Soil Sci. Soc. Am. J. 40, 655-658.

Akter, K. F., Owens, G., Davey, D. E., Naidu, R., 2005. Arsenic speciation and toxicity in biological systems. Rev. Environ. Contam. Toxicol. 184, 97-149.

Argos, M., Kalra, T., Rathouz, P. J., Chen, Y., Pierce, B., Parvez, F. et al., 2010. Arsenic exposure from drinking water, and all-cause and chronic-disease mortalities in Bangladesh (HEALS): A prospective cohort study. The Lancet 376, 252-258.

Ashe, A. J., Ludwig, Jr. E. G., 1986. The exchange reaction of tetramethyl-diphosphine, -diarsine, -distibine and -dibismuthine. J. Organome. Chem. 303, 197-204.

Bachofen, R. Birch, L., Buchs, U., Ferloni, P., Flynn, I., Jud, G. et al., 1995. Volatilization of Arsenic Compounds by Microorganisms. Bioremediation of Inorganics. Batelle Press, Columbus, Ohio, pp. 103-108.

Bartrip, P. W. J., 1994. How green was my valance?: Environmental arsenic poisoning and the victorian domestic ideal. The English Historical Rev. 109, 891-913.

Bentley, R., Chasteen, T. G., 2002. Microbial methylation of metalloids: arsenic, antimony, and bismuth. Microbiol. Mol. Biol. Rev. 66, 250-271.

Bhattacharjee, H., Rosen, B. P., 2007. Arsenic metabolism in prokaryotic and eukaryotic microbes. Molecular Microbiology of Heavy Metals, Microbiology Monographs, Heidelberg, Berlin, 6: 371-406.

Čerňanský, S., Urík, M., Ševc, J., Khun, M., 2007. Biosorption and biovolatilization of arsenic by heat-resistant fungi. Environ. Sci. Poll. Res.-Int. 14, 31-35.

Čerňanský, S., Kolenčík, M., Ševc, J., Urík, M., Hiller, E., 2009. Fungal volatilization of trivalent and pentavalent arsenic under laboratory conditions. Bioresour. Technol. 100, 1037-1040.

Challenger, F., Higginbottom, C., Ellis, L., 1933. The formation of organo-metalloidal compounds by microorganisms. Part I. Trimethylarsine and dimethylethylarsine. J. Chem. Soc. (Resumed), 95-101.

Challenger, F., 1945. Biological methylation. Chem. Rev. 36, 315-361.

Chen, J., Qin, J., Zhu, Y. G., Lorenzo, V. D., Rosen, B. P., 2013. Engineering the soil bacterium Pseudomonas putida for arsenic methylation. Appl. Environ. Microbiol. 79, 4493-4495.

Cheng, C. N., Focht, D. D., 1979. Production of arsine and methylarsines in soil and in culture. Appl. Environ. Microbiol. 38, 494-498.

Choi, S. C., Chase, Jr. T., Bartha, R., 1994. Metabolic pathways leading 
to mercury methylation in Desulfovibrio desulfuricans LS. Appl. Environ. Microbiol. 60, 4072-4077.

Cox, D. P., Alexander, M., 1973a. Effect of phosphate and other anions on trimethylarsine formation by Candida humicola. Appl. Microbiol. $25,408-413$.

Cox, D. P., Alexander, M., 1973b. Production of trimethylarsine gas from various arsenic compounds by three sewage fungi. Bull. Environ. Contam. Toxicol. 9, 84-88.

Cullen, W. R., Reimer, K. J., 1989. Arsenic speciation in the environment. Chem. Rev. 89, 713-764.

Cullen, W. R., Bentley., R., 2005. The toxicity of trimethylarsine: an urban myth. J. Environ. Monit. 7, 11-15.

Diaz-Bone, R. A., Van, De, Wiele, T. R., 2009. Biovolatilization of metal(loid)s by intestinal microorganisms in the simulator of the human intestinal microbial ecosystem. Environ. Sci. Technol. 43, 5249-5256.

Eckburg, P. B., Bik, E. M., Bernstein, C. N., Purdom, E., Dethlefsen, L., Sargent, M. et al., 2005. Diversity of the human intestinal microbial flora. Science 308, 1635-1638.

Edvantoro, B. B., Naidu, R., Megharaj, M., Merrington, G., Singleton, I., 2004. Microbial formation of volatile arsenic in cattle dip site soils contaminated with arsenic and DDT. Appl. Soil Ecol. 25, 207-217.

Frankenberger, W. T., Arshad, M., 2001. Bioremediation of seleniumcontaminated sediments and water. BioFactors 14, 241-254.

Frohne, T., Rinklebe, J., Diaz-Bone, R. A., Laing, G. D., 2011. Controlled variation of redox conditions in a floodplain soil: Impact on metal mobilization and biomethylation of arsenic and antimony. Geoderma 160, 414-424.

Gao, S. D., Burau, R. G., 1997. Environmental factors affecting rates of arsine evolution from and mineralization of arsenicals in soil. J. Environ. Qual. 26, 753-763.

Gong, Z. L., Lu, X. F., Ma, M. S., Watt, C., Chris, L. X., 2002. Arsenic speciation analysis. Talanta 58, 77-96.

Gosio, B., 1892a. Action of microphytes on solid compounds of arsenic: a recapitulation. Science 19, 104-106.

Gosio, B., 1892b. Súl riconoscimento dell'arsenico per mezzo di alcune muffe. Riv. Ig. Sanità Pubblica 3, 261-273.

Gosio, B., 1893. Action de quelques moisissures sur les composés fixes d'arsenic. Arch. Italiennes de Biologie 18, 253-265.

Honschopp, S., Brunken, N., Nehrkorn, A., Breunig, H. J., 1996. Isolation and characterization of a new arsenic methylating bacterium from soil. Microbiol. Res. 151, 37-41.

Huang, H., Jia, Y., Sun, G. X., Zhu, Y. G., 2012. Arsenic speciation and volatilization from flooded paddy soils amended with different organic matters. Environ. Sci. Technol. 46, 2163-2168.

Huysmans, K. D., Frankenberger, W. T., 1991. Evolution of trimethylarsine by a Penicillium sp. isolated from agricultural evaporation pond water. Sci. Total Environ. 105, 13-28.

Jia, Y., Huang, H., Sun, G. X., Zhao, F. J., Zhu, Y. G., 2012. Pathways and relative contributions to arsenic volatilization from rice plants and paddy soil. Environ. Sci. Technol. 46, 8090-8096.

Jia, Y., Huang, H., Zhong, M., Wang, F. H., Zhang, L. M., Zhu, Y. G., 2013. Microbial arsenic methylation in soil and rice rhizosphere. Environ. Sci. Technol. 47, 3141-3148.

Killelea, D. R., Aldstadt, J. H., 2002. Identification of dimethylchloroarsine near a former herbicide factory by headspace solid-phase microextraction gas chromatography-mass spectrometry. Chemosphere 48, 1003-1008.
Kohlmeyer, U., Kuballa, J., Jantzen, E., 2002. Simultaneous separation of 17 inorganic and organic arsenic compounds in marine biota by means of high-performance liquid chromatography/inductively coupled plasma mass spectrometry. Rapid Commun. Mass Spectrom. 16, 965-974.

Kösters, J., Diaz-Bone, R. A., Planer-Friedrich, B., Rothweiler, B., Hirner, A. V., 2003. Identification of organic arsenic, tin, antimony and tellurium compounds in environmental samples by GC-MS. J. Mol. Struct. 661-662, 347-356.

Li, G., Sun, G. X., Williams, P. N., Nunes, L., Zhu, Y. G., 2011. Inorganic arsenic in Chinese food and its cancer risk. Environ. Int. 37, 12191225.

Lin, S., Shi, Q., Nix, F. B., Styblo, M., Beck, M. A., Herbin-Davis, K. M. et al.., 2002. A novel S-adenosyl-L-methionine: arsenic(III) methyltransferase from rat liver cytosol. J. Biol. Chem. 277, 10795-10803.

Liu, S., Zhang, F., Chen, J., Sun, G. X., 2011. Arsenic removal from contaminated soil via biovolatilization by genetically engineered bacteria under laboratory conditions. J. Environ. Sci. 23, 15441550 .

Maher, W., Butler, E., 1988. Arsenic in the marine environment. Appl. Organomet. Chem. 2, 191-214.

Majumder, A., Bhattacharyya, K., Kole, S. C., Ghosh, S., 2013. Efficacy of indigenous soil microbes in arsenic mitigation from contaminated alluvial soil of India. Environ. Sci. Poll. Res. 20, 5645-5653.

McBride, B. C., Wolfe, R. S., 1971. Biosynthesis of dimethylarsine by methanobacterium. Biochemistry 10, 4312-4317.

Meharg, A., 2003. The arsenic green. Nature 423, 688.

Meng, X. Y., Qin, J., Wang, L. H., Duan, G. L., Sun, G. X., Wu, H. L. et al., 2011. Arsenic biotransformation and volatilization in transgenic rice. New Phytol. 191, 49-56.

Mester, Z., Sturgeon, R. E., 2001. Detection of volatile arsenic chloride species during hydride generation: a new prospectus. J. Anal. Atom. Spectrom. 16, 470-474.

Mestrot, A., Feldmann, J., Krupp, E. M., Hossain, M. S., Roman-Ross, G., Meharg, A. A., 2011. Field fluxes and speciation of arsines emanating from soils. Environ. Sci. Technol. 45, 1798-1804.

Mestrot, A., Planer-Friedrich, B., Feldmann, J., 2013. Biovolatilization: a poorly studied pathway of the arsenic biogeochemical cycle. Environ. Sci.: Processes and Impacts, doi: 10.1039/C3EM00105A.

Meyer, J., Schmidt, A., Michalke, K., Hensel, R., 2007. Volatilization of metals and metalloids by the microbial population of an alluvial soil. Syst. Appl. Microbiol. 30, 229-238.

Meyer, J., Michalke, K., Kouril, T., Hensel, R., 2008. Volatilisation of metals and metalloids: an inherent feature of methanoarchaea? Syst. Appl. Microbiol. 31, 81-87.

Michalke, K., Wickenheiser, E. B., Mehring, M., Hirner, A. V., Hensel, R., 2000. Production of volatile derivatives of metal(loid)s by microflora involved in anaerobic digestion of sewage sludge. Appl. Environ. Microbiol. 66, 2791-2796.

Michalke, K., Meyer, J., Hirner, A, V., Hensel, R., 2002. Biomethylation of bismuth by the methanogen Methanobacterium formicicum. Appl. Organomet. Chem. 16, 221-227.

Michalke, K., Schmidt, A., Huber, B., Meyer, J., Sulkowski, M., Hirner, A. V. et al., 2008. Role of intestinal microbiota in transformation of bismuth and other metals and metalloids into volatile methyl and hydride derivatives in humans and mice. Appl. Environ. Microbiol. 74, 3069-3075. 
Mohapatra, D., Mishra, D., Chaudhury, G. R., Das, R. P., 2008. Removal of arsenic from arsenic rich sludge by volatilization using anaerobic microorganisms treated with cow dung. Soil Sediment Contam. 17, 301-311.

Pakulska, D., Czerczak, S., 2006. Hazardous effects of arsine: a short review. Int. Occup. Med. Environ. Health 19, 36-44.

Pantsar-Kallio, M., Korpela, A., 2000. Analysis of gaseous arsenic species and stability studies of arsine and trimethylarsine by gas chromatography-mass spectrometry. Anal. Chimi. Acta 410, 6570.

Pearce, R. B., Callow, M. E., Macaskie, L. E., 1998. Fungal volatilization of arsenic and antimony and the sudden infant death syndrome. FEMS Microbiol. Lett. 158, 261-265.

Pickett, A. W., Mcbride, B. C., Cullen, W. R., 1988. Metabolism of trimethylarsine oxide. Appl. Organomet. Chem. 2, 479-482.

Planer-Friedrich, B., 2004. Volatile arsenic in aquatic environments. PhD Thesis. Technische Universität Bergakademie Freiberg, Department of Geology, Freiberg, Germany.

Planer-Friedrich, B., Lehr, C., Matschullat, J., Merkel, B. J., Nordstrom, D. K., Sandstrom, M. W., 2006. Speciation of volatile arsenic at geothermal features in Yellowstone National Park. Geochim. Cosmochim. Acta 70, 2480-2491.

Qin, J., Rosen, B. P., Zhang, Y., Wang, G. J., Franke, S., Rensing, C., 2006. Arsenic detoxification and evolution of trimethylarsine gas by a microbial arsenite S-adenosylmethionine methyltransferase. Proc. Natl. Acad. Sci. USA 103, 2075-2080.

Qin, J., Lehr, C. R., Yuan, C. G., Le, X. C., Mcdermott, T. R., Rosen, B. P., 2009. Biotransformation of arsenic by a Yellowstone thermoacidophilic eukaryotic alga. Proc. Natl. Acad. Sci. USA 106, 5213-5217.

Sanford, R. A., Klein, D. A., 1988. Environmental bioremediation for organometallic compounds: Microbial growth and arsenic volatillization from soil and retorted shale. Appl. Organom. Chem. 2, $159-169$.

Shariatpanahi, M., Anderson, A. C., Abdelghani, A. A., Englande, A. J., Hughes, J., Wilkinson, R. F., 1981. Biotransformation of the pesticide sodium arsenate. J. Environ. Sci. Health Part B: Pesticides, Food Contam. Agric. Wastes, 16, 35-47.

Shariatpahani, M., Anderson, A. C., Abdelghani, A. A., Englande, A. J., 1983. Microbial metabolism of an organic arsenical herbicide, in: Oxley, T. A., Barry, S. (Eds.), Biodeterioration. John Wiley and Sons, Chichester, United Kingdom, pp. 268-277.

Sohel, N., Persson, L, A., Rahman, M., Streatfield, P. K., Yunus, M., Ekström, E. C. et al., 2009. Arsenic in drinking water and adult mortality a population-based cohort study in rural Bangladesh. Epidemiol. 20, 824-830.

Srivastava., P. K.., Vaish, A., Dwivedi, S., Chakrabarty, D., Singh, N., Tripathi, R. D., 2011. Biological removal of arsenic pollution by soil fungi. Sci. Total Environ. 409, 2430-2442.

Su, S. M., Zeng, X. B., Bai, L. Y., Jiang, X. L., Li, L. F., 2010. Bioaccumulation and biovolatilization of pentavalent arsenic by Penicillin janthinellum, Fusarium oxysporum and Trichoderma asperellum under laboratory conditions. Curr. Microbiol. 61, 261266.
Tesfalidet, S., Irgum, K., 1988. Volatilization of arsenic as the trichloride for sample introduction in atomic spectroscopy. Anal. Chem. 60, 2031-2035.

Thomas, F., Diaz-Bone, R. A., Wuerfel, O., Huber, B., Weidenbach, K., Schmitz, R. A. et al., 2011. Connection between multimetal(loid) methylation in methanoarchaea and central intermediates of methanogenesis. Appl. Environ. Microbiol. 77, 8669-8675.

Thompson-Eagle, E. T., Frankenberger, W. T., Karslon, U., 1989. Volatilization of selenium by Alternaria alternata. Appl. Environ. Microbiol. 55, 1406-1413.

Turpeinen, R., Pantsar-Kallio, M., Kairesalo, T., 2002. Role of microbes in controlling the speciation of arsenic and production of arsines in contaminated soils. Sci.Total Environ. 285, 133-145.

Urík, M., Čerňanský, S., Ševc, J., Šimonovičová, A., Littera, P., 2007. Biovolatilization of arsenic by different fungal strains. Water, Air, Soil Poll. 186, 337-342.

Valette-Silver, N. J., Riedel, G. F., Crecelius, E. A., Windom, H., Smith, R. G., Dolvin, S. S., 1999. Elevated arsenic concentrations in bivalves from the southeast coasts of the USA. Mar. Environ. Res. 48, 311-333.

Van, De, Wiele, T., Gallawa, C. M., Kubachk, K. M., Creed, J. T., Basta, N., Dayton, E. A. et al., 2010. Arsenic metabolism by human gut microbiota upon in vitro digestion of contaminated soils. Environ. Health Perspect. 118, 1004-1009.

Visoottiviseth, P., Panviroj, N., 2001. Selection of fungi capable of removing toxic arsenic compounds from liquid medium. Sci. Asia, 27: 83-92.

Wang, S. L., Mulligan, C. N., 2006. Occurrence of arsenic contamination in Canada: sources, behavior and distribution. Sci. Total Environ. 366, 701-721.

Wickenheiser, E. B., Michalke, K., Drescher, C., Hirner, A. V., Hensel, R., 1998. Development and application of liquid and gas-chromatographic speciation techniques with element specific (ICP-MS) detection to the study of anaerobic arsenic metabolism. Fresenius' J. Anal. Chem. 362, 498-501.

Woolson, E. A., Kearney, P. C., 1973. Persistence and reactions of ${ }^{14}$ Ccacodylic acid in soils. Environ. Sci. Technol. 7, 47-50.

Ye, J., Rensing, C., Rosen, B. P., Zhu, Y. G., 2012. Arsenic biomethylation by photosynthetic organisms. Trends in Plant Sci. 17, 155-162.

Yin, X. X., Chen, J., Qin, J., Sun, G. X., Rosen, B. P., Zhu, Y. G., 2011a. Biotransformation and volatilization of arsenic by three photosynthetic cyanobacteria. Plant Physiol. 156, 1631-1638.

Yin, X. X., Zhang, Y. Y., Yang, J., Zhu, Y. G., 2011b. Rapid biotransformation of arsenic by a model protozoan Tetrahymena thermophila. Environ. Poll. 159, 837-840.

Zhang, S. Y., Sun, G. X., Yin, X. X., Rensing, C., Zhu, Y. G., 2013. Biomethylation and volatilization of arsenic by the marine microalgae Ostreococcus tauri. Chemosphere doi: 10.1016/j.bbr.2011.03.031.

Zhang, Y. Y., Yang, J., Yin, X. X., Yang, S. P., Zhu, Y. G., 2012. Arsenate toxicity and stress responses in the freshwater ciliate Tetrahymena pyriformis. Eur. J. Protistol. 48, 227-236.

Zhao, F. J., Ma, J. F., Meharg, A. A., McGrath, S. P., 2009. Arsenic uptake and metabolism in plants. New Phytol. 181, 777-794. 